\title{
PENERAPAN METODE AUTOREGRESSIVE INTEGRATED MOVING AVERAGE (ARIMA) UNTUK PREDIKSI BILANGAN SUNSPOT
}

\section{Application of Autoregressive Integrated Moving Average (ARIMA) Method for Sunspot Number Prediction}

\author{
Felia Dria Yuliawanti ${ }^{1}$, Dian Candra Rini Novitasari ${ }^{2 *}$, Nanang Widodo ${ }^{3}$, \\ Abdulloh Hamid ${ }^{4}$, Wika Dianita Utami ${ }^{5}$ \\ 1,2,4,5 Matematika, Fakultas Sains dan Teknologi, UIN Sunan Ampel Surabaya, \\ ${ }^{3}$ Balai Pengamatan Antariksa dan Atmosfer Pasuruan \\ 1,2,4,5 Jl. Ahmad Yani No.117, Surabaya, 60237, Indonesia \\ ${ }^{3} J l$. Raya Gempol - Mojokerto Km.03, Pasuruan, 67155, Indonesia \\ Corresponding authore-mail: 2*diancrini@uinsby.ac.id
}

\begin{abstract}
Abstrak
Peristiwa magnetik pada matahari ditandai dengan salah satu tanda yaitu munculnya sunspot atau bintik matahari. Sunspot terletak di fotosfer matahari yang memiliki warna lebih gelap dari pancaran sekitarnya. Tujuan dari penelitian ini adalah untuk memprediksi bilangan sunspot dengan menggunakan metode ARIMA. Metode ARIMA dilakukan dengan melihat plot ACF dan PACF untuk mendapatkan model yang akan digunakan dalam prediksi. Penelitian ini menggunakan data bilangan sunspot yang dimulai dari bulan Januari tahun 1987 hingga bulan Desember 2019 sebanyak 396 data. Dari data tersebut didapatkan 4 model ARIMA yaitu ARIMA $(3,1,2)$, $\operatorname{ARIMA}(3,1,1), \operatorname{ARIMA}(2,1,2), \operatorname{ARIMA}(2,1,1)$. Dari keempat model tersebut, model terbaik yang digunakan untuk prediksi yaitu ARIMA $(2,1,2)$ dengan nilai AIC sebesar $-884,87$.
\end{abstract}

Kata Kunci : Prediksi, Sunspot, Autoregressive Integrated Moving Average, ARIMA

Abstract

One of the magnetic events in the sun is the appearance of sunspots. The sunspot is located in the sun's photosphere and has a darker colour than the surrounding radiance. The purpose of this research was to predict sunspot numbers using the ARIMA method. The ARIMA method is done by looking at the ACF and PACF plots to get a model that will be used in the predictions. The data used in this research is sunspot number data that started from January 1987 to December 2019 as many as 396 data. From the data obtained 4 models of ARIMA namely ARIMA(3,1,2), ARIMA(3,1,1), ARIMA(2,1,2), ARIMA(2,1,1). Of the four models, the best prediction model is ARIMA(2,1,2) by an AIC value of $-884,87$.

Keywords: Prediction, Sunspot, Autoregressive Integrated Moving Average, ARIMA

Submitted: $15^{\text {th }}$ April $2021 \quad$ Accepted: $29^{\text {th }}$ July 2021

How to cite this article:

F. D. Yuliawanti, D. C. R. Novitasari, N. Widodo, A. Hamid, and W. D. Utami, "PENERAPAN METODE AUTOREGRESSIVE INTEGRATED MOVING AVERAGE (ARIMA) UNTUK PREDIKSI BILANGAN SUNSPOT', BAREKENG: J. Il. Mat. \& Ter., vol. 15, no. 03, pp. 555-564, Sep. 2021.

This work is licensed under a Creative Commons Attribution-ShareAlike 4.0 International License.

Copyright @ 2021 Felia Dria Yuliawanti, Dian Candra Rini Novitasari, Nanang Widodo, Abdulloh Hamid, Wika Dianita Utami 


\section{PENDAHULUAN}

Matahari merupakan sumber yang sangat penting bagi kehidupan manusia, karena memiliki sumber energi yang tak terbatas. Pada fotosfer matahari terdapat fenomena sunspot [1]. Sunspot merupakan perpotongan tabung medan magnet matahari dengan fotosfer yang terjadi karena aktivitas medan magnet yang sangat kuat pada permukaan matahari yang dipengaruhi oleh rotasi diferensial matahari [2], [3]. Sunspot memiliki warna gelap dibandingkan sekitarnya di permukaan matahari dikarenakan suhu yang dimiliki lebih rendah daripada suhu fotosfer yaitu sekitar $4000^{\circ} \mathrm{K}$ sampai $4500^{\circ} \mathrm{K}$ [4], [5]. Munculnya sunspot menunjukkan adanya daerah aktif di matahari, jika daerah aktif semakin luas kemunculannya berpotensi besar menyebabkan terjadinya flare (ledakan matahari) [6]. Sunspot juga memiliki dampak buruk pada iklim dan cuaca di bumi sehingga dapat mengganggu aktivitas manusia [7]. Sunspot memiliki periode rata-rata satu siklus matahari sekitar 11 tahun, sedangkan untuk periode siklus polaritas sunspot adalah sekitar 22 tahun yang dicatat berdasarkan time series (runtun waktu). Data time series dapat digunakan untuk memprediksi data di masa mendatang. Oleh karena itu, prediksi baik digunakan untuk mengantisipasi dampak buruk yang ditimbulkan oleh sunspot. Banyak metode yang dapat digunakan untuk prediksi dengan data time series salah satunya adalah metode ARIMA [4], [8].

Metode ARIMA merupakan salah satu metode time series yang ditemukan pada tahun 1970 oleh George Box dan Gwilym Jenkins sehingga metode ini juga dapat disebut dengan Box-Jenkins [9], [10]. Metode ARIMA sangat efisien untuk digunakan sebagai prediksi jangka pendek secara cepat karena hanya memanfaatkan data variabel yang hendak diramalkan saja dan memiliki akurasi yang baik [11].

Terdapat beberapa penelitian terdahulu yang menggunakan metode ARIMA untuk melakukan prediksi, antara lain penelitian tentang prediksi harga bitcoin didapatkan model ARIMA $(0,2,1)$ dengan nilai MAPE yang baik yaitu sebesar 4,753\% [12]. Selain itu pada penelitian lain tentang prediksi harga gula pasir di Jakarta yang membandingkan metode ARIMA dengan MA diperoleh model terbaiknya adalah $\operatorname{ARIMA}(2,1,1)$, sedangkan untuk metode MA kurang sesuai karena hasil peramalan untuk 30 hari ke depan menunjukkan hasil yang sama [13]. Metode ARIMA juga baik digunakan untuk meramal pergerakan inflasi daripada metode AR dan MA, dengan nilai Sum Square Error ARIMA, AR dan MA masing-masing sebesar 23,22; 31,51 dan 577,36 [11]. Sementara, pada penelitian tentang bilangan sunspot didapatkan model AR(1) atau ARIMA $(1,0,0)$ dengan nilai koefisien korelasi sebesar 96,5\% [10]. Lalu pada penelitian estimasi tren dan perkiraan univariat dari bilangan sunspot dikatakan bahwa model ARMA $(11,1)$ dan $\operatorname{ARIMA}(8,1,1)$ baik digunakan untuk meramalkan rata-rata bilangan sunspot tahunan [14].

Berdasarkan referensi dan beberapa penelitian mengenai sunspot dan metode ARIMA di atas, akan dilakukan penelitian tentang memprediksi bilangan sunspot bulanan dengan menggunakan metode ARIMA. Penelitian ini diharapkan dapat memprediksi sunspot untuk mengantisipasi efek buruk yang ditimbulkan bagi keadaan antariksa dan bumi sehingga tidak mengganggu aktivitas manusia.

\section{METODE PENELITIAN}

Pada ARIMA, terdapat beberapa metode yang berkaitan yaitu Autoregressive, Moving Average, Autoregressive Moving Average dan Autoregressive Integrated Moving Average (ARIMA). Autoregressive merupakan sebuah metode dimana data pada periode sebelumnya sangat berdampak atau berpengaruh terhadap data saat ini [10], [12].

$$
Z_{t}=\phi_{1} Z_{t-1}+\phi_{2} Z_{t-2}+\ldots+\phi_{p} Z_{t-p}-e_{t}
$$

Keterangan

$Z_{t}:$ deret waktu

$\phi_{p}:$ parameter autoregressive

$e_{t}:$ nilai error

Moving Average merupakan model yang pertama kali dikenalkan pada tahun 1973 oleh Slutzky dan kemudian pada tahun 1989 dikembangkan oleh Wadsworth [10], [12].

$$
Z_{t}=e_{t}-\theta_{1} e_{t-1}-\cdots-\theta_{q} e_{t-q}
$$


Keterangan

$Z_{t}:$ deret waktu

$\theta_{q}:$ parameter moving average

$e_{t}:$ nilai error

Autoregressive Moving Average merupakan model yang mengkombinasikan antara Autoregressive dan Moving Average dengan bentuk umum sebagai berikut [10], [12].

$$
Z_{t}=\emptyset_{1} Z_{t-1}+\cdots+\emptyset_{p} Z_{t-p}+e_{t}-\theta_{1} e_{t-1}-\cdots-\theta_{q} e_{t-q}
$$

Keterangan

$Z_{t}:$ deret waktu

$\emptyset_{p}$ : parameter autoregressive

$e_{t}:$ nilai error

$\theta_{q}:$ parameter moving average

ARIMA merupakan model dengan dugaan data yang digunakan harus stasioner dengan mean dan varians, sehingga dibutuhkan proses differencing (pembedaan) yang tidak sanggup dijelaskan oleh model AR, MA dan ARMA [12].

$$
\phi_{p}(B) D^{d} Z_{t}=\mu+\theta_{q}(B) e_{t}
$$

Keterangan

$\phi_{p}:$ parameter autoregressive

$\theta_{q}:$ parameter moving average

$B$ : operator backshift

$D$ : differencing

$\mu$ : konstanta

$e_{t}:$ nilai error

$p:$ derajat autoregressive

$q:$ derajat moving average

$d$ : tingkat differencing

Penelitian ini menggunakan data bilangan sunspot setiap bulan yang diperoleh dari https://www.sidc.be/silso/ [7]. Data yang digunakan sebanyak 396 data yang dimulai dari bulan Januari tahun 1987 hingga bulan Desember 2019 dengan variabel terikat (Y) yaitu bilangan sunspot dan variabel bebas (X) yaitu periode waktu yang ditunjukkan pada Tabel 1, sebagai berikut:

Tabel 1. Data bilangan sunspot

\begin{tabular}{ccc}
\hline Tahun & Bulan & Bilangan sunspot \\
\hline 1987 & 1 & 9,8 \\
\hline 1987 & 2 & 3,4 \\
\hline 1987 & 3 & 17,4 \\
\hline$\vdots$ & $\vdots$ & $\vdots$ \\
\hline 2019 & 11 & 0,5 \\
\hline 2019 & 12 & 1,5 \\
\hline \multicolumn{3}{c}{ Sumber data: [7] }
\end{tabular}

Dalam menyelesaikan permasalahan pada penelitian ini, dilakukan beberapa tahapan metode ARIMA sebagai berikut:

1. Pengumpulan data bilangan sunspot dari tahun 1987 hingga 2019 serta menentukan variabel terikat (Y) dan variabel bebas (X).

2. Normalisasi data

Salah satu metode untuk normalisasi adalah min-max. Normalisasi min-max merupakan metode yang menskala ulang data dari rentang yang lama ke rentang yang baru dengan rentang yang digunakan antara 0 dan 1 [15], [16]. 


$$
x^{\prime}=\frac{x-\min \left\{x_{k}\right\}}{\max \left\{x_{k}\right\}-\min \left\{x_{k}\right\}}
$$

Keterangan

$x^{\prime}$ : nilai normalisasi

$x$ : nilai data

$\min \left\{x_{k}\right\}$ : nilai minimal dari suatu data

$\max \left\{x_{k}\right\}$ : nilai maksimal dari suatu data

3. Identifikasi

Identifikasi dilakukan melalui plot dari data time series, sehingga diketahui kestasioneran sebuah data [17]. Data yang digunakan harus stasioner terhadap mean dan varians [18]. Jika data time series tidak stasioner, maka diperlukan proses differencing untuk menstasionerkan data terhadap mean dan ini sudah menjadi bagian dari pemodelan ARIMA [19], [20].

$$
Z_{t}^{\prime}=Z_{t}-Z_{t-1}
$$

Keterangan

$Z_{t}^{\prime}:$ nilai data yang di-defferencing

$Z_{t}:$ nilai data aktual

Sedangkan untuk transformasi digunakan pada data yang tidak stasioner terhadap varians dengan transformasi Box-Cox [19].

$$
T\left(Z_{t}\right)=\frac{Z_{t}^{\lambda}-1}{\lambda}
$$

Keterangan

$T\left(Z_{t}\right)$ : nilai data yang ditransformasi

$Z_{t}:$ nilai data aktual

$\lambda$ : diperoleh dari metode maksimum likelihood

Jika data telah stasioner, maka bisa didapatkan model $\operatorname{ARIMA}(p, d, q)$ dengan $d$ merupakan tingkat differencing data, orde $p$ dan orde $q$ merupakan lag yang keluar dari garis signifikan atau garis putusputus pada plot PACF (Partial Autocorrelation Function) dan plot ACF (Autocorrelation Function) [17].

4. Estimasi Parameter

Dari beberapa model yang sudah diperoleh, kemudian dilakukan uji hipotesis agar dapat mengetahui signifikansi suatu parameter dengan hipotesis awal $H_{0}$ : parameter tidak signifikan dan $H_{1}$ : parameter signifikan. Untuk kriteria uji yang digunakan yaitu $H_{0}$ ditolak jika $p$-value $<\alpha(5 \%=0,05)$ [12], [18].

Jika terdapat lebih dari satu model $\operatorname{ARIMA}(p, d, q)$ yang memenuhi hipotesis $H_{1}$, maka dapat dipilih satu model terbaik dengan nilai AIC yang paling rendah [21]. Akaike Information Criteria (AIC) banyak digunakan pada model statistik untuk mengukur tingkat kesesuaian model. Pada saat membandingkan dua atau lebih sebuah model, model dengan nilai AIC paling rendah dianggap lebih mendekati data aktual [22].

$$
\operatorname{AIC}\left(P^{*}\right)=\frac{2 p^{*}}{n}+\frac{-2 \ln L\left(P^{*}\right)}{n}
$$

Keterangan

$L\left(P^{*}\right)$ : nilai maksimum likelihood

$p^{*}$ : jumlah parameter $\beta, p^{*}=1,2, \ldots, p$

$n$ : jumlah data

5. Uji diagnostik

Uji diagnostik dilakukan setelah uji signifikansi estimasi dari suatu parameter untuk membuktikan apakah model sudah cukup baik atau tidak [17]. Model akan dikatakan baik jika asumsi dari distribusi 
normal dan residual white noise terpenuhi. Untuk mengetahui residual dikatakan white noise atau tidak dapat menggunakan Uji Ljung-Box sebagai berikut [19].

$$
Q=n(n+2) \sum_{k=1}^{K} \hat{\rho}_{k}^{2}(n-k)^{-1}
$$

Keterangan

$n$ : banyak data

$k$ : nilai lag

$K$ : nilai maksimum lag

$\hat{\rho}_{k}:$ nilai ACF

Sedangkan, untuk asumsi distribusi normal dengan menggunakan Jarque Bera Test. Metode ini berasal dari perbandingan seberapa jauh ukuran asimetri dan kurtosis yang berbeda dari karakteristik nilai distribusi normal. Kriteria uji yang digunakan adalah jika nilai $J B>\alpha=0,05$ maka data berdistribusi normal dan begitu juga sebaliknya [23], [24].

$$
J B=\frac{N}{6} S K+\frac{N}{24} K U
$$

Keterangan

JB : Jarque Bera

$S K$ : kemiringan

$K U$ : ukuran kurtosis

6. Data aktual yang sebelumnya dinormalisasi akan dikembalikan ke data aktual semula atau didenormalisasikan.

7. Model ARIMA yang sudah didapat kemudian digunakan untuk menentukan prediksi di masa mendatang. Prediksi dengan metode ini dikatakan baik daripada menggunakan model ekonometri tradisional [11].

\section{HASIL DAN PEMBAHASAN}

Pada penelitian ini, data yang diperoleh akan digunakan untuk memprediksi bilangan sunspot enam bulan berikutnya yaitu bulan 1 hingga bulan 6 tahun 2020 .

Berdasarkan data pada Tabel 1 yang sudah diperoleh, data akan dinormalisasi terlebih dahulu untuk mengisi data yang bernilai nol. Setelah data dinormalisasi kemudian dibuat plot data dan plot ACF untuk mengidentifikasi kestasioneran data.

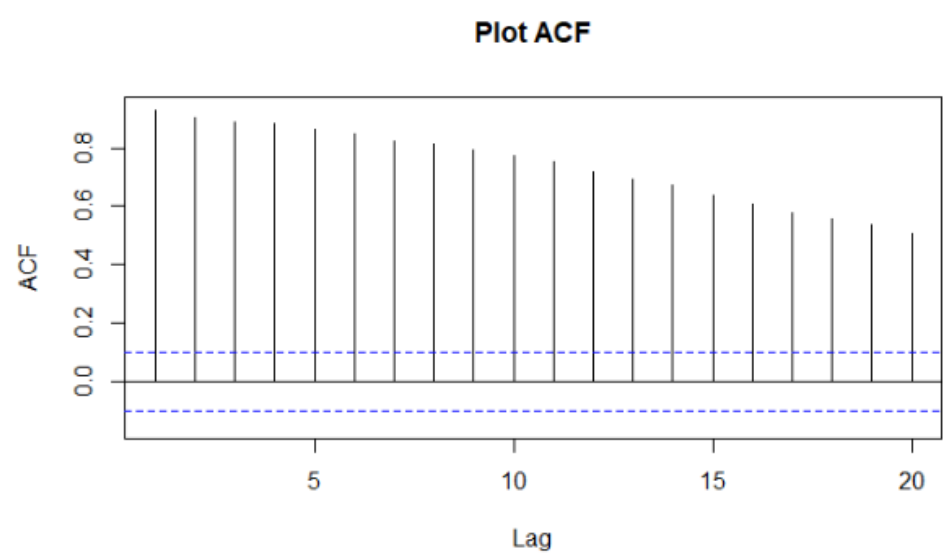

(a) 


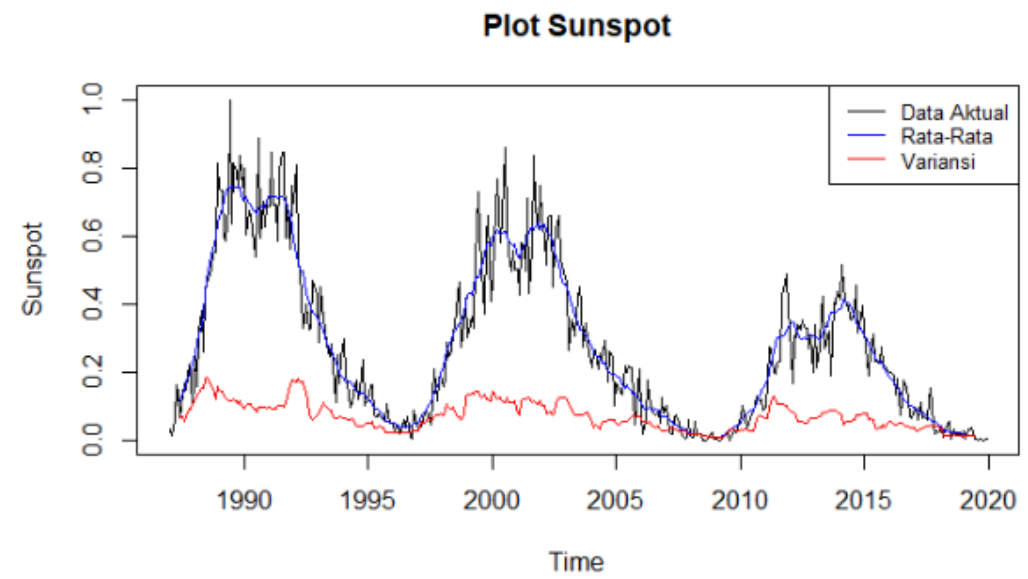

(b)

Gambar 1. (a) Plot ACF, (b) Plot data bilangan sunspot

Pada Gambar 1 (a) terlihat bahwa plot ACF lag ke-1 hingga lag ke-20 keluar dari garis putus-putus atau garis signifikan, sehingga dapat dikatakan data tersebut tidak stasioner. Sedangkan pada Gambar 1 (b) dapat dilihat bahwa varians sudah konstan terhadap waktu. Kemudian pada data aktual terlihat bahwa data tidak konstan terhadap waktu. Lalu pada mean juga tidak konstan terhadap waktu dan bergerak mengikuti plot data aktual. Karena data aktual dan mean tidak konstan, maka data dikatakan tidak stasioner terhadap mean, sehingga perlu dilakukan differencing tingkat satu.

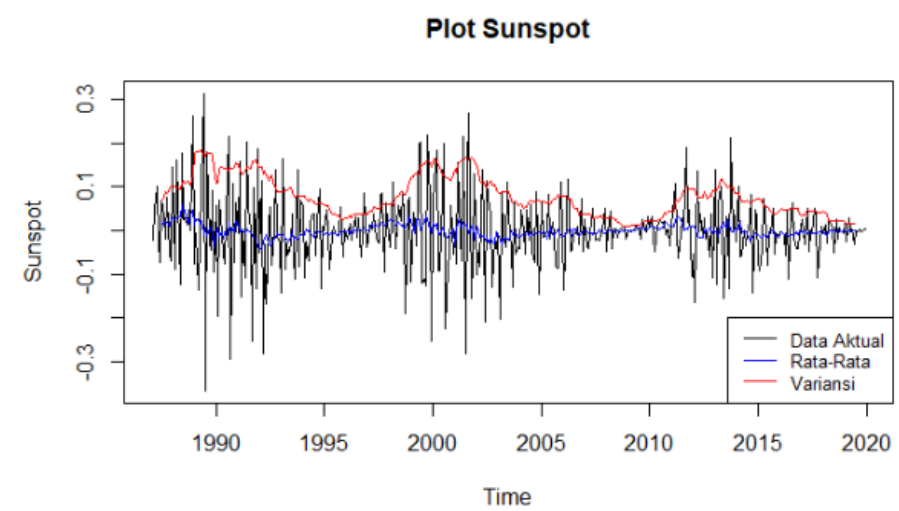

(a)
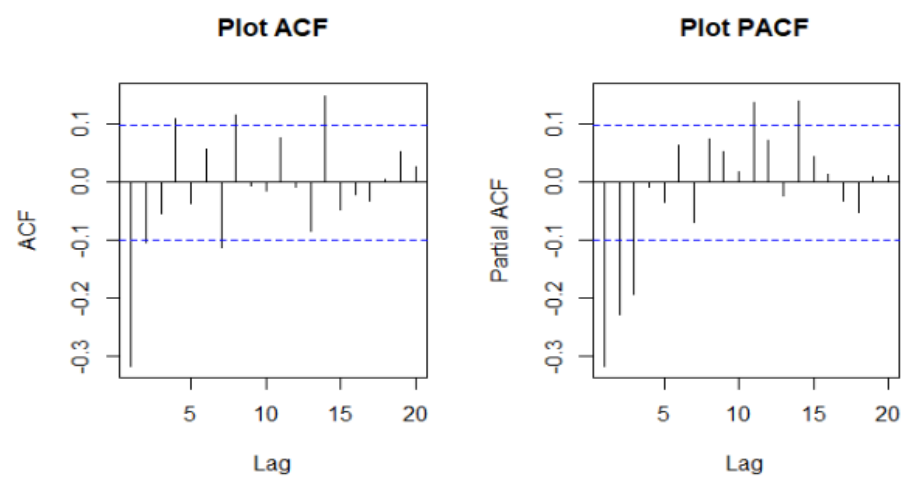

(b)

Gambar 2. (a) Plot sunspot yang sudah stasioner, (b) plot ACF dan PACF yang sudah stasioner

Pada Gambar 2 (a) dapat dilihat bahwa data aktual, mean dan varians sudah konstan terhadap waktu yang berarti data sudah stasioner. Karena data sudah stasioner maka dapat ditentukan model $\operatorname{ARIMA}(p, d, q)$ dengan orde $p$ merupakan lag yang keluar dari signifikan pada plot PACF dan orde $q$ merupakan lag yang keluar dari garis putus-putus/signifikan pada plot ACF serta $d$ yang merupakan tingkat differencing pada data 
yaitu satu. Dari Gambar 2 (b) didapatkan model sementara ARIMA yaitu ARIMA(3,1,2), ARIMA(3,1,1), $\operatorname{ARIMA}(2,1,2)$, dan $\operatorname{ARIMA}(2,1,1)$.

Tabel 2. Estimasi parameter

\begin{tabular}{|c|c|c|c|c|}
\hline \multirow{2}{*}{ Model } & \multicolumn{4}{|c|}{ Estimasi Parameter } \\
\hline & Tipe & AIC & p-value & Kriteria \\
\hline \multirow{5}{*}{$\operatorname{ARIMA}(3,1,2)$} & $\operatorname{AR}(1)$ & \multirow{5}{*}{$-881,61$} & 0,0000 & Signifikan \\
\hline & $\operatorname{AR}(2)$ & & 0,4138 & Tidak signifikan \\
\hline & $\operatorname{AR}(3)$ & & 0,0112 & Signifikan \\
\hline & MA(1) & & 0,0000 & Signifikan \\
\hline & MA(2) & & 0,0004 & Signifikan \\
\hline \multirow{4}{*}{$\operatorname{ARIMA}(3,1,1)$} & $\mathrm{AR}(1)$ & \multirow{4}{*}{$-879,3$} & 0,1946 & Tidak signifikan \\
\hline & $\operatorname{AR}(2)$ & & 0,0225 & Signifikan \\
\hline & $\mathrm{AR}(3)$ & & 0,0310 & Signifikan \\
\hline & MA(1) & & 0,8360 & Tidak signifikan \\
\hline \multirow{4}{*}{$\operatorname{ARIMA}(2,1,2)$} & $\mathrm{AR}(1)$ & \multirow{4}{*}{$-884,87$} & 0,0000 & Signifikan \\
\hline & $\operatorname{AR}(2)$ & & 0,0107 & Signifikan \\
\hline & MA(1) & & 0,0000 & Signifikan \\
\hline & MA(2) & & 0,0000 & Signifikan \\
\hline \multirow{3}{*}{$\operatorname{ARIMA}(2,1,1)$} & $\mathrm{AR}(1)$ & \multirow{3}{*}{$-877,5$} & 0,6793 & Tidak signifikan \\
\hline & $\mathrm{AR}(2)$ & & 0,1077 & Tidak signifikan \\
\hline & MA(1) & & 0,0000 & Signifikan \\
\hline
\end{tabular}

Berdasarkan pada Tabel 2, setelah dilakukan estimasi parameter pada kelima model di atas diketahui bahwa model ARIMA $(2,1,2)$ signifikan karena $p$-value $<\alpha=0,05$ dan nilai $\operatorname{AIC~ARIMA(2,1,2)~lebih~rendah~}$ dari yang lainnya yaitu sebesar $-884,87$. Oleh karena itu, model $\operatorname{ARIMA}(2,1,2)$ akan digunakan untuk prediksi.
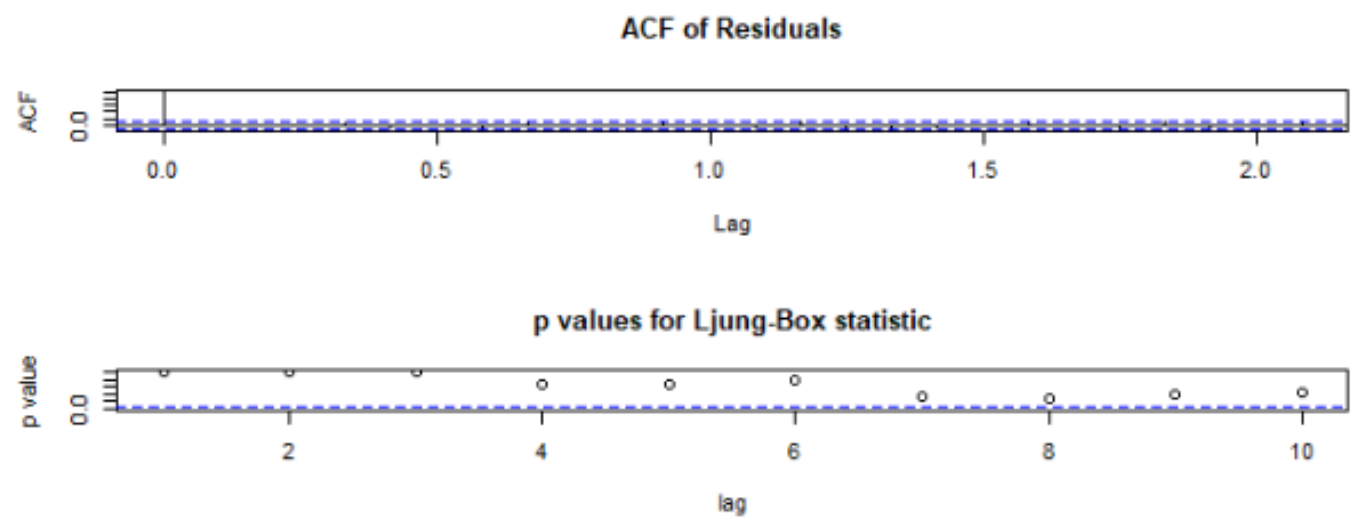

Gambar 3. Uji diagnostik

Pada Gambar 3 terlihat bahwa plot residual ACF tidak menunjukkan adanya lag yang keluar dari garis putus-putus atau garis signifikan, sehingga residualnya dikatakan white noise. Sedangkan pada plot statistik Ljung-Box, diketahui $p$-value $>\alpha=0,05$ yang berarti tidak terdapat autokorelasi. Kemudian dilakukan uji normalitas dengan Jarque Bera Test dan didapatkan $p$-value sebesar $1,125 \times 10^{-9}<\alpha=0,05$ yang menunjukkan bahwa distribusi normal tidak terpenuhi. Sebelum dilakukan prediksi, data aktual yang sebelumnya dinormalisasi akan dikembalikan ke data aktual semula atau didenormalisasikan.

Tabel 3. Perbandingan data prediksi dan data aktual

\begin{tabular}{cccc}
\hline Tahun & Bulan & Data Aktual & Data Prediksi \\
\hline 2020 & 1 & 6,2 & 1,0135777 \\
\hline 2020 & 2 & 0,2 & 0,5536694 \\
\hline 2020 & 3 & 1,5 & 0,1601057 \\
\hline 2020 & 4 & 5,2 & $-0,1628287$ \\
\hline 2020 & 5 & 0,2 & $-0,4226707$ \\
\hline 2020 & 6 & 5,8 & $-0,6297593$ \\
\hline
\end{tabular}




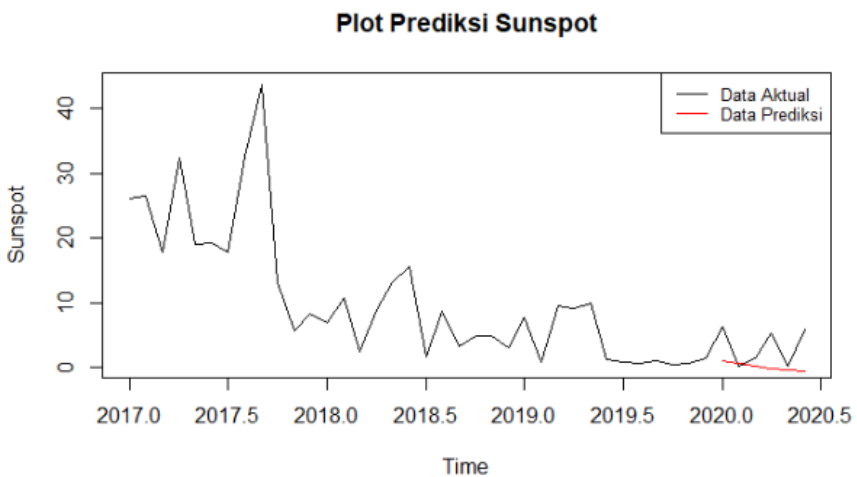

(a)

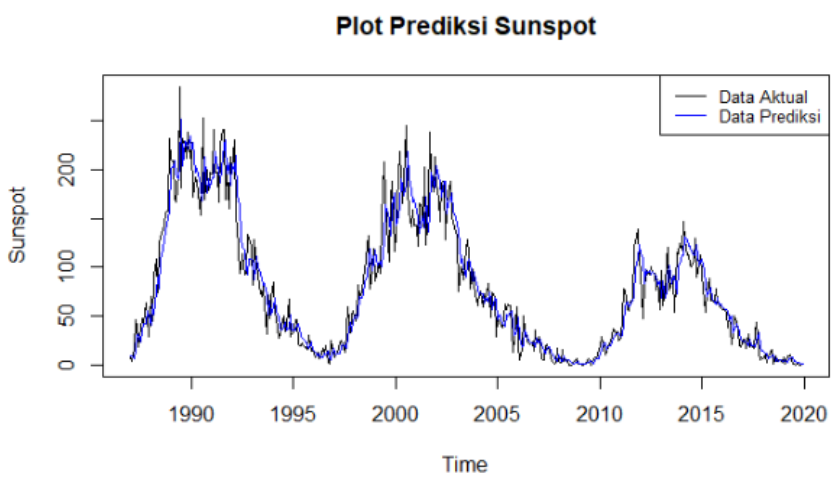

(b)

\section{Gambar 4 (a) Plot data prediksi dan aktual sunspot Tahun 2017-2020, (b) Plot data prediksi dan aktual sunspot Tahun 1987-2019}

Tabel 3 merupakan prediksi bilangan sunspot pada bulan 1 hingga bulan 6 tahun 2020. Pada Tabel 3 terlihat hasil prediksi yang didapatkan berbeda jauh dengan data aktual sesuai dengan grafik yang berwarna merah pada Gambar 4 (a). Pada bulan kedua memiliki hasil prediksi yang mendekati data aktual daripada di bulan lainnya. Meskipun memiliki hasil prediksi yang jauh berbeda, akan tetapi memiliki grafik yang bergerak mengikuti data aktual seperti yang ditunjukkan pada Gambar 4 (b).

Hasil prediksi dengan metode ARIMA yang jauh berbeda juga terdapat pada penelitian tentang perbandingan metode ARIMA dengan RBFNN untuk meramalkan rata-rata banyaknya bilangan sunspot [4]. Pada penelitian ini data yang digunakan tidak berdistribusi normal, karena itu untuk penelitian selanjutnya diharapkan menggunakan metode nonparametrik seperti metode Support Vector Regression (SVR) agar mendapatkan hasil prediksi yang lebih baik [7].

\section{KESIMPULAN}

Berdasarkan hasil dan pembahasan prediksi bilangan sunspot menggunakan metode ARIMA dengan data bilangan sunspot setiap bulan yang dimulai dari tahun 1987 hingga tahun 2019 didapatkan 4 model ARIMA yaitu ARIMA(3,1,2), ARIMA(3,1,1), $\operatorname{ARIMA}(2,1,2), \operatorname{ARIMA}(2,1,1)$. Dari keempat model tersebut diperoleh satu model tebaik yang digunakan untuk prediksi yaitu model $\operatorname{ARIMA}(2,1,2)$ dengan nilai AIC sebesar $-884,87$.

\section{UCAPAN TERIMA KASIH}

Terima kasih kepada Balai Pengamatan Antariksa dan Atmosfer Pasuruan yang telah memberikan kesempatan, waktu dan ilmu yang bermanfaat sehingga peneliti dapat menyusun jurnal ini. Tak lupa juga peneliti berterima kasih kepada dosen pembimbing, dosen lapangan serta semua pihak yang telah membantu menyusun jurnal ini. Peneliti berharap jurnal ini dapat bermanfaat bagi semua pihak. 


\section{DAFTAR PUSTAKA}

[1] D. Hasanah, R. A, "Pengelompokkan Sunspot pada Citra Matahari dengan Menggunakan K-Means Clustering," MathVisioN, vol. 01, no. 02, pp. 72-78, 2019, [Online]. Available: url:http://journal.unirow.ac.id/index.php/mv.

[2] S. Nisa', Estimator Kernel Epanechnikov dan Kernel Triangle pada Data Rata-Rata Bulanan Bilangan Sunspot, NOAA. Undergraduate [thesis]. Malang: Universitas Islam Negeri Maulana Malik Ibrahim, 2016. [Online]. Available: http://etheses.uin-malang.ac.id/2895/.

[3] G. S. Budhi, R. Adipranata, M. Sugiarto, B. Anwar, and B. Setiahadi, "Pengelompokan Sunspot Pada Citra Digital Mahatari Menggunakan Metode Clustering Dbscan,” Semin. Nas. Apl. Teknol. Inf. 2011, vol. 2011, no. Snati, pp. 17-18, 2011, [Online]. Available: https://www.neliti.com/publications/176344/pengelompokan-sunspot-pada-citra-digital-mahatari-menggunakanmetode-clustering.

[4] M. A. Zufar, Perbandingan Metode ARIMA dengan RBFNN dalam Peramalan Rata-Rata Banyaknya Bilangan Sunspot. Undergraduate [thesis]. Malang: Universitas Islam Negeri Maulana Malik Ibrahim, 2018. [Online]. Available: http://etheses.uin-malang.ac.id/13954/.

[5] Y. Monita, D. C. R. Novitasari, N. Widodo, and A. Z. Arifin, "Penggunaan Metode Backpropagation Untuk Peramalan Jumlah Ledakan Matahari (Flare)," MathVisioN, vol. 1, no. 02, pp. 67-71, 2019, [Online]. Available: url:http://journal.unirow.ac.id/index.php/mv.

[6] U. Yus'an and E. Puspitaningrum, "Mendeteksi Aktivitas Matahari dengan Mengamati Evolusi Plage dan Sunspot Menggunakan Software Kesehatan," Media Dirgant., vol. 9, no. 4, 2014, [Online]. Available: https://majalah.lapan.go.id/index.php/md/article/download/245/232.

[7] S. Suwanto, Prediksi Bilangan Sunspot menggunakan Support Vector Regression (SVR). Undergraduate [thesis]. Surabaya: Universitas Islam Negeri Sunan Ampel, 2019. [Online]. Available: http://digilib.uinsby.ac.id/id/eprint/38114.

[8] W. E. Cahyono, "Dampak Aktivitas Matahari Terhadap Kenaikan Temperatur Global," J. Ber. Dirgant., vol. 11, no. 1, pp. 15, 2010, [Online]. Available: http://jurnal.lapan.go.id/index.php/berita_dirgantara/article/view/1159.

[9] A. Lusiani, "Pemodelan Autoregressive Integrated Moving Average (ARIMA) Curah Hujan Di Kota Bandung," Sigma-Mu, vol. 3, pp. 9-25, 2011, [Online]. Available: https://jurnal.polban.ac.id/sigmamu/article/view/874.

[10] B. A. Marzouk, "Statistical method to predict the sunspots number," NRIAG J. Astron. Geophys., vol. 7, no. 2, pp. 175-179, 2018, [Online]. Available: https://doi.org/10.1016/j.nrjag.2018.08.001.

[11] H. Hartati, "Penggunaan Metode Arima Dalam Meramal Pergerakan Inflasi," J. Mat. Sains dan Teknol., vol. 18, no. 1, pp. 110, 2017, [Online]. Available: http://jurnal.ut.ac.id/index.php/jmst/article/view/163.

[12] N. Salwa, N. Tatsara, R. Amalia, and A. F. Zohra, "Peramalan Harga Bitcoin Menggunakan Metode ARIMA (Autoregressive Integrated Moving Average)," J. Data Anal., vol. 1, no. 1, pp. 21-31, 2018, [Online]. Available: http://www.jurnal.unsyiah.ac.id/JDA/article/view/11874.

[13] A. A. Wiliyana, M. Y. Darsyah, and U. M. Semarang, "Perbandingan Metode ARIMA Dan Moving Average Pada Kasus Harga Gula Pasir Di Jakarta," Pros. Semin. Nas. Mhs. Unimus, vol. 1, pp. 361-367, 2018, [Online]. Available: https://www.researchgate.net/profile/Moh_Darsyah/publication/339350281_Perbandingan_Metode_ARIMA_Dan_MOVING _AVERAGE_Pada_Kasus_Harga_Gula_Di_Jakarta/links/5e4ca3bf92851c7̄f7f457594/Perbandingan-Metode-ARIMA-DanMOVING-AV̄ERAGE-Pada-Kasus-Harga-Gula-Di-Jakarta.pdf.

[14] S. Chattopadhyay, D. Jhajharia, and G. Chattopadhyay, "Trend estimation and univariate forecast of the sunspot numbers: Development and comparison of ARMA, ARIMA and Autoregressive Neural Network models," Comptes Rendus - Geosci., vol. 343, no. 7, pp. 433-442, 2011, [Online]. Available: http://dx.doi.org/10.1016/j.crte.2011.07.008.

[15] D. A. Nasution, H. H. Khotimah, and N. Chamidah, "Perbandingan Normalisasi Data untuk Klasifikasi Wine Menggunakan Algoritma K-NN," Comput. Eng. Sci. Syst. J., vol. 4, no. 1, p. 78, 2019, [Online]. Available: https://jurnal.unimed.ac.id/2012/index.php/cess/article/view/11458.

[16] N. Chamidah, . W., and U. Salamah, "Pengaruh Normalisasi Data pada Jaringan Syaraf Tiruan Backpropagasi Gradient Descent Adaptive Gain (BPGDAG) untuk Klasifikasi," J. Teknol. Inf. ITSmart, vol. 1, no. 1, p. 28, 2016, [Online]. Available: https://jurnal.uns.ac.id/itsmart/article/view/582.

[17] M. L. Tauryawati and M. I. Irawan, "Perbandingan Metode Fuzzy Time Series Cheng dan Metode Box-Jenkins untuk Memprediksi IHSG," J. Sains dan Seni ITS, vol. 3, no. 2, pp. A34-A39, 2014, [Online]. Available: http://ejurnal.its.ac.id/index.php/sains_seni/article/view/7985.

[18] R. N. Anityaloka and A. N. Ambarwati, "Peramalan Saham Jakarta Islamic Index Menggunakan Metode ARIMA Bulan MeiJuli 2010," Statistika, vol. 1, no. 1, pp. 1-5, 2013, [Online]. Available: http://103.97.100.145/index.php/statistik/article/view/733.

[19] W. H. Lailiyah and D. Manuharawati, "Penerapan Metode Autoregressive Integrated Moving Average (Arima) pada Peramalan Nilai Ekspor Di Indonesia," Ilm. Mat., vol. 6, no. 3, pp. 45-52, 2018, [Online]. Available: https://jurnalmahasiswa.unesa.ac.id/index.php/mathunesa/article/view/26373.

[20] A. Sutcliffe, "Time-series forecasting using fractional differencing," J. Forecast., vol. 13, no. 4, pp. 383-393, 1994, [Online]. Available: https://onlinelibrary.wiley.com/doi/abs/10.1002/for.3980130404.

[21] R. Nurmalasari and D. Ispriyanti, “Analisis Faktor-Faktor Yang Mempengaruhi Indeks Pembangunan Manusia (IPM),” Bul. Ilm. Math.Stat dan Ter., vol. 8, no. 1, pp. 111-120, 2019, [Online]. Available: http://ejournal-s1.undip.ac.id/index.php/gaussian.

[22] P. Mondal, L. Shit, and S. Goswami, "Study of Effectiveness of Time Series Modeling (Arima) in Forecasting Stock Prices," Int. J. Comput. Sci. Eng. Appl., vol. 4, no. 2, pp. 13-29, 2014, [Online]. Available: https://www.researchgate.net/publication/276197260.

[23] C. Domański, "Properties of Jarque-Bera test," Acta Univ. Lodz. Folia Oeconomica, vol. 235, no. 6 2, 2010, [Online]. Available: http://cejsh.icm.edu.pl/cejsh/element/bwmeta1.element.hdl_11089_340.

[24] R. Wahyudi and L. Martha, "Analisis Modal Intelektual Dan Kinerja Keuangan Serta Pengaruhnya Terhadap Nilai Perusahaan," INA-Rxiv, 2019, [Online]. Available: https://osf.io/preprints/inarxiv/j5e9u/. 
